\title{
Komu svěřit posuzování a přezkum žádostí o mezinárodní ochranu?
}

\section{Who Should be Entitled to Decide on and to Review Applications for International Protection?}

\author{
Jana Jurníková**, Alžbeta Králová***
}

\begin{abstract}
Abstrakt
Zvýšné migračni toky prïspèly ke znovnotevreni diskusi obledně systému zpracováni a prèzkumu žádostí o mezinárodni ocbranu jak na unijní, tak na národni úrovni. Debata na vnitrostátni úrovni je ovlivnèna rovněž potrebou implementace povinnosti zajistit úplné a ex nunc posouzeni skutkové i právni stránky, věet-

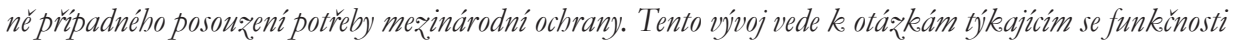
stávajicího nastaveni rozhodujicího orgánu a prezkumu roz̧odnutí o mezinárodni ochranè, zejména otázce, komu by mèlo být svěreno rozhodováni a prezkeum azylových žádostí. Cllánek se zaměruje na možné żmèny týkajici se rozhodujicího orgánu a systému soudního prezkumu v azylových vècech, který momentálné zcela neodpovídá revidované procedurálni smèrnici.
\end{abstract}

\section{Klíčová slova}

asyl; mezinárodni ochrana; roz̧̧odujici orgán; soudni prèzkum; procedurálni smèrnice; úplný a ex nunc prèzkum.

\section{Abstract}

Increased migration flows reopen the debates related to the system of processing and reviewing applications for international protection on EU level, as well as on the national level. The debate on national level is influenced also by the need to implement the obligation to provide full and ex nunc examination of both facts and points of law, including the international protection needs. This development leads to the questions related to the functionality of current system of determining authorities in asylum matters and the system of review of decisions on international protection, more particularly to the question which authority should decide on and review the applications in asylum matters. The article focuses on the possible amendments with respect to determining authorities and with respect to system of judicial review in asylum matters that currently does not fully comply with revised Procedures Directive.

\section{Keywords}

Asylum; International Protection; Determining Authority; Judicial Review; Procedures Directive; Full and ex nunc Review.

* Článek vznikl jako dílčí výstup projektu specifického výzkumu Vliv unijního práva na úpravu opravných prostředků v cizineckém právu (MUNI/A/1207/2014).

** JUDr. Jana Jurníková, Ph.D., Katedra správní vědy a správního práva, Právnická fakulta Masarykovy univerzity, Brno / Department of Administrative Studies and Administrative Law, Faculty of Law, Masaryk University, Brno, Czech Republic / orcid.org/0000-0001-7130-6486 / E-mail: jana.jurnikova@mail.muni.cz

*** Mgr. Bc. Alžbeta Králová, doktorandka, Katedra správní vědy a správního práva, Právnická fakulta Masarykovy univerzity, Brno / Ph.D. student, Department of Administrative Studies and Administrative Law, Faculty of Law, Masaryk University, Brno, Czech Republic / E-mail: alzbeta.kralova@mail.muni.cz 


\section{1 Úvod}

Stávající uprchlická krize představuje předmět diskusí jak na národní, tak na unijní úrovni. Tzv. společný evropský azylový systém, který byl od roku 1999 budován s cílem vytvoření jednotných pravidel pro určování státu odpovědného za posouzení žádosti o mezinárodní ochranu, jednotných standardů pro azylová řízení, minimálních přijímacích podmínek pro žadatele o azyl a sbližování pravidel pro přiznávání statusu azylanta, ${ }^{1}$ vykazuje pod zvýšeným náporem žadatelů o mezinárodní ochranu významné nedostatky a i ze strany představitelů Evropské unie se objevují hlasy volající po jeho revizi. ${ }^{2}$ $\mathrm{Na}$ vnitrostátní úrovni je pak debata vedena nejenom ohledně koncepčních otázek spojených s uprchlickou krizí, ale také ve vztahu k o něco techničtější otázce implementace revidované procedurální směrnice ${ }^{3}$, jejîž transpoziční lhůta uplynula v červenci 2015. Procedurální směrnice totiž kromě jiných úprav azylového řízení přináší změny týkající se rozsahu soudního přezkumu, a to prostřednictvím požadavku na „úplné a ex nunc “ posouzení jak skutkové, tak právní stránky rozhodnutí o mezinárodní ochraně.

Kombinace zvýšeného počtu žadatelů o mezinárodní ochranu v rámci celé Evropské unie, nových požadavků kladených na úpravu řízení o mezinárodní ochraně procedurální směrnicí, společně se zvýšeným akcentováním práva na účinnou soudní ochranu ve smyslu článku 47 Listiny základních práv Evropské unie, vytváří předpoklady pro znovuotevření diskuse o tom, komu by mělo být svěřeno rozhodování ve věcech mezinárodní ochrany a následné posouzení v rámci řízení o opravném prostředku. Cílem článku je proto reflexe stávající unijní i vnitrostátní úpravy orgánů kompetentních pro posuzování azylových žádostí i pro rozhodnutí o opravných prostředcích ve věcech mezinárodní ochrany.

\section{Orgán odpovědný za posouzení žádosti}

Jedním z rysů současné fáze budování společného evropského azylového systému je roztřriššenost orgánů posuzujících žádosti v azylových řízeních. Každý členský stát svými vnitrostátními právními předpisy určuje orgán věcně a místně př́slušný k projednání žádosti. Podmínky, které je nutno splnit, určuje procedurální směrnice v článku 2 písm. f), který definuje rozhodující orgán jako „kvazisoudní nebo správní orgán člen-

1 Viz Závěry zasedání Evropské rady v Tampere konaného ve dnech 15. a 16. ř́jina 1999.

2 Viz kupř. vyjádření předsedy Evropské komise Jean-Claude Junckera Responsabilité et solidarité: un an à la Commission européenne. Projev predsedy Jean-Claude Junckera prü plenárním zasedání Rady pro ekonomii, sociálni véci a životni prostredí ze dne 28. řjjna 2015 [online]. Evropská komise, 2015 [cit. 8. 11. 2015]. Dostupné z: http:// europa.eu/rapid/press-release_SPEECH-15-5946_en.htm. Obdobně viz i návrhy reformy v rámci Sděleni Komise Evropskému parlamentu a Radě. Zlepšit společný evropský ayylový systém a zdokonalit qákonné možnosti. $\operatorname{COM}(2016) 197$ final [online]. Brusel, 6. 4. 2016 [cit. 14. 5. 2016]. Dostupné z: https://ec.europa.eu/ transparency/regdoc/rep/1/2016/CS/1-2016-197-CS-F1-1.PDF

3 Směrnice Evropského parlamentu a Rady 2013/32/EU o společných řízeních pro přiznávání a odnímání statusu mezinárodní ochrany. 
ského státu př́slušný $\mathrm{k}$ posuzování žádostí o mezinárodní ochranu a prríslušný k přijímání rozhodnutí v prvním stupni v těchto prrípadech“. Článek 4 procedurální směrnice nicméně umožňuje, aby se na určitých činnostech, které jsou zde definovány, podílel i orgán jiný (obvykle zařazený do policejní složky). Výjimky jsou omezeny na zpracování žádostí podle nařízení Dublin III $^{4}$ a řízení na hranicích. Ve srovnání s pưvodní směrnicí Rady 2005/85/ES o minimálních normách pro řízení v členských státech o přiznávání a odnímání postavení uprchlíka, je tak seznam činností mnohem užší a nezahrnuje rozhodování o žádosti s přihlédnutím k vnitrostátním bezpečnostním předpisům, či předběžné posuzování vybraných typů žádostí. ${ }^{5}$ Procedurální směrnice váže státy v případě, kdy využijí možnosti výše uvedených výjimek, zajistit, aby osoby konající dané činnosti disponovaly patřičnými znalostmi nebo jim poskytnout školení. Určení rozhodujícího orgánu představuje autonomní prostor členského státu a odráží vnitrostátní pojetí rozhodovacích procesů a vnímání samotné mezinárodní ochrany.

Cílům definovaným v procedurální směrnici v podobě myšlenky společného azylového řízení v Evropské unii by nejlépe korespondoval model jednoho orgánu odpovědného za posuzování azylových žádostí. Tento orgán by měl prímo rozhodovací pravomoc, v prrípadě kladného rozhodnutí by tedy byl žadateli přiznán azyl Evropské unie. ${ }^{6}$ Konkrétní členský stát, zpravidla ten, na jehož území se daná osoba nachází, by dále zabezpečil vlastní realizaci postavení azylanta, tj. práva z něj vyplývající (právo pobytu, integrační programy apod.). Existence jednoho orgánu by vedla ke sjednocení posuzování žádostí, odstranila by rozdíly v interpretaci jednotlivých ustanovení národními orgány a plně by realizovala jednotné normy azylového rrízení. Přestože stávající uprchlická krize vede k akcentování jednotného př́stupu k azylovým žádostem7, a kromě jednotného zpracování azylových žádostí se objevují diskuse i o externím zpracování žádostí, představuje posuzování žádostí o mezinárodní ochranu orgánem Evropské unie stále nerealizovatelný ideál. Lze si nicméně představit minimálně posilování kompetencí Evropského podpůrného úřadu pro otázky azylu, který by v širší míře vypracovával informace o zemích

4 Nařízení Evropského parlamentu a Rady (EU) č. 604/2013 ze dne 26. června 2013, kterým se stanoví kritéria a postupy pro určení členského státu př́slušného k posuzování žádosti o mezinárodní ochranu podané státním príslušníkem třetí země nebo osobou bez státní příslušnosti v některém z členských států.

5 Viz COSTELLO, Cathryn a Emily HANCOX. The Recast Asylum Procedures Directive 2013/32/EU: Caught between the Stereotypes of the Abusive Asylum Seeker and the Vulnerable Refugee [online]. Oxford Legal Studies Research Paper No. 33/2015, 2015 [cit. 8. 11. 2015]. Dostupné z: http://ssrn.com/abstract=2609897

6 Obdobně srovnej návrhy ECRE. Towards Fair and Efficient Asylum Systems in Europe [online]. Září 2016 [cit. 8. 11. 2015]. Dostupné z: http://www.ecre.org/component/downloads/downloads/97.html. K jednotnému zpracování žádostí viz i EVROPSKÁ KOMISE. Study on the Feasibility and legal and practical implications of establishing a mechanism for the joint processing of asylum applications on the territory of the EU [online]. Pub. 13. 2. 2013 [cit. 8. 11. 2015]. Dostupné z: http://ec.europa.eu/dgs/home-affairs/e-library/documents/ policies/asylum/common-procedures/docs/jp_final_report_final_en.pdf

7 EVROPSKÁ KOMISE. Evropský program promigraci. $\operatorname{COM}(2015) 240$ final. [online]. Pub. 13. 5. 2015 [cit. 8. 11. 2015]. Dostupné z: http://eur-lex.europa.eu/legal-content/CS/TXT/ $\mathrm{PDF} /$ ?uri=CELEX:52015DC0240\&from $=\mathrm{EN}$ 
původu a poskytoval asistenci v azylovém ř́izení. Přestože se těmto činnostem věnuje již nyní, nečiní tak v rozsahu, který by zásadně ovlivnil a urychlil řízení v jednotlivých členských státech, na což upozorňuje i Evropská komise, která již předložila návrh na vytvoření Agentury EU pro otázky azylu se značně posíleným mandátem. ${ }^{8}$

\subsection{Závislý či nezávislý orgán?}

Každý členský stát realizuje azylové řízení prostřednictvím orgánu, do jehož kompetence rozhodování svěřily vnitrostátní předpisy, a to v závislosti na struktuře veřejné správy a organizaci soudnictví. Svoji tradici má rozhodování v azylových věcech v první instanci ve veřejné správě, kdy rozhoduje orgán moci výkonné. Může se jednat o speciálně zrrízený správní orgán, jehož kompetencí jsou pouze věci azylové, nebo správní orgán, který řeši i jiné záležitosti a $\mathrm{v}$ rámci svojí vnitřní struktury zahrnuje odbor zabývající se azylovými ř́́zeními. Sylvie Da Lomba rozlišuje dva modely orgánů posuzujících žádosti v první instanci. První z nich je představován orgánem, který je na vládě nezávislý, druhý model staví na posuzování žádostí orgánem, který je součástí vládních orgánů. ${ }^{9} \mathrm{Na}$ prvnî pohled by se mohlo zdát, že model první, spočívající v delegaci rozhodování ve věcech azylu v první instanci mimo systém vládních orgánů, zaručí nezávislost rozhodování na vládní politice a bude tedy dobrým předpokladem pro lepší ochranu žadatelů a liberálnější prrístup k výkladu kritérií Ženevské úmluvy. Př́ikladem realizace tohoto modelu je Francie, kde o žádostech rozhoduje l'Office français de protection des réfugiés et apatridés, kterou lze vymezit jako veřejnou instituci mající právní subjektivitu a disponující správní i finanční autonomií. ${ }^{10}$ Jak však namítá Sylvie Da Lomba, tento orgán, i přes deklaraci své autonomie, často při rozhodování zohledňuje vládní politiku a je př́íkladem uspořádání, kde vynesení rozhodování o azylu mimo vládní strukturu nemusí samo o sobě nutně znamenat nezávislost rozhodování. ${ }^{11}$

Požadavkem procedurální směrnice není svěření rozhodování do rukou nezávislého orgánu na vládě. At’ již má posuzování žádostí ve své kompetenci orgán závislý na vládě, či naopak na ní nezávislý, ve všech případech je členský stát povinen zajistit objektivnost a nestrannost posuzování žádosti. ${ }^{12}$ Jistou pojistku nestrannosti v rozhodovacím procesu zná sama procedurální směrnice, když stanoví, že podkladem pro rozhodnutí mají být

8 Viz návrh nařízení Evropského parlamentu a Rady o Agentuře Evropské unie pro otázky o azylu a o zrušení nařízení (EU) 439/2010. COM(2016) 271 final [online]. Brusel, 4. 5. 2016 [cit. 14. 5. 2016]. Dostupné z: http://ec.europa.eu/dgs/home-affairs/what-we-do/policies/european-agenda-migration/ proposal-implementation-package/docs/20160504/easo_proposal_en.pdf

9 DA LOMBA, Sylvia. The right to seek refugee status in the European Union. Antwerp-Oxford-New York: Intersentia, 2004, s. 185.

10 Srov. čl. L 721-1 Code de l'entrée et du séjour des étrangers et du droit d'asile In: Legifrance [právní informační systém]. Secrétariat général du gouvernement [cit. 8. 11. 2015].

11 DA LOMBA, op. cit., s. 185.

12 Srov. čl. 10 odst. 3 písm. a) procedurální směrnice. 
informace přesné a aktuální, ale především vícezdrojové ${ }^{13}$, např. z UNHCR, Podpưrného úřadu, Human Rights Watch, ale taktéž zpráv vycházejících z činnosti např. ministerstev. ${ }^{14}$ Výsledek rozhodování by měl být přímo závislý na posouzení daného prrípadu z hlediska naplnění podmínek pro poskytnutí mezinárodní ochrany a měl by eliminovat jiné, především politické faktory na rozhodování o žádosti.

\subsection{Udělení mezinárodní ochrany nejen v první instanci aneb více hráčů}

Vzhledem k vícestupňovosti řízení je vždy nutné vysledovat, které orgány jsou příslušné k posouzení žádosti v azylových věcech s vlastní kompetencí rozhodnout o udělení mezinárodní ochrany. Právo na účinný opravný prostředek představuje zakotvení principu dvojstupňovosti rozhodovacího procesu jako minimálního požadavku. ${ }^{15}$ Při posuzování toho, kdo je oprávněn mezinárodní ochranu přiznat, je tudíž nutné zohlednit celý systém orgánů podílejících se na posuzování žádosti, včetně orgánů řazených do systému kontroly rozhodování. Součástí tohoto systému jsou orgány, do jejichž kompetence náleží rozhodování o opravných prostředcích a je věcí národního práva, jaká koncepce je zde uplatněna: zda je tedy orgán př́slušný o dané věci rozhodnout s konečnou platností, tj. mezinárodní ochranu udělit, nebo rozhodnutí zrušit a věc vrátit orgánu, který ji opětovně posoudí.

Z institucionálního hlediska rozhodují o opravném prostředku zpravidla správní soudy nebo tzv. správní tribunály ${ }^{16}$, přičemž posouzení žádosti může předcházet i opravný prostředek uplatněný v režimu veřejné správy. O žádosti tedy rozhodne správní orgán (at' už v podobě speciálně zřízeného správního orgánu nebo příslušného odboru správního orgánu), jehož rozhodnutí je podrobeno přezkumu bud' nadřízeného správního orgánu, nebo prímo soudu či správního tribunálu. Orgán, který rozhoduje o opravném prostředku, v prrípadě konstatování pochybení mezinárodní ochranu bud’ sám přizná, nebo věc vrací zpět správnímu orgánu, tedy výkonné moci, který žádost opětovně posoudí. V modelu prvním je tak i přezkumný orgán oprávněn k udělení mezinárodní ochrany, přičemž v rámci řízení je přezkoumávána stránka jak faktická, tak i právní. ${ }^{17} \mathrm{O}$ žádosti postupně

13 Srov. čl. 10 odst. 2 písm. b) procedurální směrnice.

14 Kritéria, které by měla být naplněna u informací o zemi původu, formuloval Nejvyšší správní soud v rozsudku ze dne 4. února 2009, sp. zn. 1 Azs 105/2008.

15 Myšlenka práva dvou opravných prostředků, tedy zakotvení tří stupňů v rozhodovacím procesu, nakonec členskými státy přijata nebyla, viz KOSAŘ, David. Zjevně nedůvodné žádosti o azyl (mezinárodní ochranu) a jejich soudní přezkum. In: JÍLEK, Dalibor a Renata KLEČKOVÁ. Společný evropský azylový systém: procedurální smérnice. Brno: Doplněk, 2006, s. 173.

16 Myšlenka správních tribunálů byla zvažována i v České republice, srov. usnesení vlády č. 322 ze dne 9. dubna 2001 k Analýze problematiky správních tribunálů s vymezením jejich postavení, působnosti, zřizování, složení a řízení před nimi.

17 Srov. KOPALOVÁ, Michaela. Spravedlnost v řízení o opravných prostředcích. In: JÍLEK, Dalibor a Renata KLEČKOVÁ. Společný evropský asylový systém: procedurální směrnice. Brno: Doplněk, 2006, s. 137. 
rozhoduji ${ }^{18}$ dva orgány a každý z nich je mezinárodní ochranu oprávněn udělit. V modelu druhém, kdy orgán rozhodující o opravném prostředku nemá kompetenci mezinárodní ochranu prriznat, přezkoumává napadené rozhodnutí z hlediska možných vad a v př́padě jejich konstatování rozhodovací proces vrací zpět správnímu orgánu, který o věci opětovně rozhoduje s tím, že je povinen respektovat konstatovaný právní názor.

Procedurální směrnice ve vztahu k opravnému prostředku stanovuje, aby o něm rozhodoval soud nebo tribunál, přičemž explicitně nezakotvuje nutnost svěřit soudu nebo tribunálu pravomoc mezinárodní ochranu přímo udělit. Oproti směrnici č. 2005/85/ES nicméně dochází k zásadnímu posunu, jenž se týká rozsahu soudního přezkumu. Článek 46 odst. 3 totiž stanovuje povinnost, „aby účinný opravný prostředek obsahoval úplné a ex nunc posouzení jak skutkové, tak právní stránky, včetně případného posouzení potřeby mezinárodní ochrany...". Je otázkou, co přesně požadavek na „úplné“ posouzení jak skutkové, tak právní stránky věci znamená. Marcelle Reneman se s odkazem na judikaturu Soudního dvora ${ }^{19}$ kloní k tomu, že soud musí provést skutečné posouzení skutkových i právních otázek, zahrnující posouzení toho, zda jsou zjištěné skutkové okolnosti správné, věrohodné, konzistentní, zda důkazy poskytují dostatek informací k posouzení komplexní situace a zda z nich lze dovodit provedené závěry. ${ }^{20}$ Není tedy nutné plně nahradit skutkové posouzení rozhodujícího správního orgánu. ${ }^{21}$ I výše uvedená „restriktivnější interpretace rozsahu přezkumu, která nevyžaduje plné nahrazení posouzení správního orgánu, implikuje schopnost práce s informacemi o zemích původu a přístup k informačním databázím. Kromě rozsahu přezkumu procedurální směrnice nově zakotvuje i moment, k němuž je přezkum prováděn a explicitně stanovuje povinnost zohlednit skutkový stav k momentu soudního přezkumu, což odpovídá zásadě non-refoulement ${ }^{22}$. Právě požadavek přezkumu ex nunc v kombinaci s nutností případného posouzení potřeby mezinárodní ochrany vede $\mathrm{k}$ závěru o př́klonu $\mathrm{k}$ modelu, $\mathrm{v}$ rámci kterého soud mezinárodní ochranu přímo udělí. V momentě, kdy soud provádí úplné a ex nunc posou-

18 Jako př́klad tohoto modelu lze uvést azylové řízení Francie, kde je žadatel oprávněn se odvolat ke „Cour nationale du droit d'asile“ (Národní azylový soud). Tento vykonává působnost speciálních správních soudů a je označovaná jako tzv. kvazisoud, srov. SLÁDEČEK, Vladimír; TOMOSZKOVÁ, Veronika a kol. Správni soudnictvi v Ceské republice a ve vybraných státech Evropy. Praha: Wolters Kluwer, 2010, s. 231.

19 Rozsudek Soudního dvora ze dne 15. února 2005, ve věci C-13/03 P Komise Evropských společenství proti Tetra Laval, který se sice věnuje přezkumu konglomerátních spojení soutěžitelů, obdobně jako v azylových věcech ale zde dochází k jisté predikci budoucího vývoje, srovnej COSTELLO, Cathryn. The European asylum procedures directive in legal context. Research Paper No. 134 [online]. UNHCR, 2006 [cit. 8. 11. 2015]. Dostupné z: http://www.unhcr.org/4552f1cc2.html, s. 30.

20 RENEMAN, Marcelle. EU asylum procedures and the right to an effective remedy. Oxford: Hart publishing, 2014, s. 282.

21 RENEMAN, op. cit., s. 283.

22 V tomto ohledu lze nicméně odkázat i na nález Ústavního soudu ze dne 12. 4. 2016, sp. zn. I. ÚS 425/16, ve kterém Ústavní soud dovodil povinnost zohlednit povahu nových skutečností a situaci konkrétního žadatele i z práva na účinný prostředek nápravy ve smyslu čl. 13 Úmluvy o ochraně lidských práv a základních svobod a čl. 36 odst. 2 Listiny základních práv a svobod, resp. z účinnosti práva na azyl podle čl. 43 Listiny. 
zení jak skutkové, tak právní stránky, za tímto účelem doplňuje dokazování v souvislosti se změnou situace $\mathrm{v}$ zemi původu a má navíc posoudit potřebu mezinárodní ochrany, měl by mít právo mezinárodní ochranu přímo udělit. Vrácení věci správnímu orgánu ve fázi, kdy soud provedl přezkum v potřebném rozsahu a dospěl k závěru o potřebě mezinárodní ochrany, se jeví být nadbytečným a neefektivním krokem. Nutno však poznamenat, že jednoznačný a explicitní požadavek na přímé udělení mezinárodní ochrany soudem nebo tribunálem z procedurální směrnice neplyne.

\section{Odpovědný orgán v podmínkách azylového rrízení v České republice}

\subsection{Historické souvislosti}

Svoje první zkušenosti se zařazením azylových řízení z hlediska kompetencí a dělby moci ve státě prožila České republika v roce 1990, kdy byl projednáván a schvalován zákon o uprchlících. Vzhledem ke skutečnosti, že se vlastně jednalo o specifickou oblast cizineckého práva, kde bylo silné zastoupení Policie ČR, byla i oblast uprchlictví svěřena do segmentu veřejné správy, a to správy vnitřní. Podle $\int 9$ zákona č. 498/1990 Sb., o uprchlících, bylo k řízení príislušné federální Ministerstvo vnitra, po rozdělení federace na dva samostatné unitární státy jím bylo Ministerstvo vnitra. Rozhodování tak bylo posunuto prrímo na centrální úroveň v podobě ústředního správního orgánu. Silná vazba na policejní složky byla potvrzena využitím ustanovení \ 2 odst. 2 zák. č. 289/1991 Sb., o Policii České republiky, ve znění pozdějších předpisů, a ministerstvo pověřilo vedením řízení v první instanci Ředitelství služby cizinecké a pohraniční policie. Fakticky tak byla sloučena agenda ve věcech cizineckého práva bez přihlédnutí ke specifikům práva uprchlického. K vyčlenění rozhodování z policejní složky na civilní došlo až v ř́jnu roku 1998, kdy se řízení ujalo Ministerstvo vnitra. V první instanci byl př́slušným odborem k vedení řízení Odbor pro uprchlíky a integraci cizinců, proti jehož rozhodnutí bylo možné podat rozklad, o němž rozhodoval ministr vnitra.

Model zahrnující opravný prostředek v podobě rozkladu byl převzat azylovým zákonem. Rozklad je však jako opravný prostředek proti rozhodnutí ústředního orgánu státní správy v prvním stupni sám o sobě velice problematický, jelikož v podstatě dochází $\mathrm{k}$ rozdělení rrízení v rámci jednoho správního orgánu a z tohoto úhlu pohledu je jako druh opravného prostředku velice často kritizován. ${ }^{23}$ Přestože $v$ prrípadě bezchybného fungování může představovat jistý filtr a odlehčit správnímu soudnictví, v případě azylových řízení se delší dobu jevil jako nevhodný. ${ }^{24}$ Negativní rysy rozkladu měly být sice

23 Viz kupř. VAČOK, Juraj. Možno vždy považovat’ rozklad za prostriedok nápravy? In: NECKÁř, Jan et al. (eds.). Dny práva - 2008 - Days of Law [online]. Brno: Masarykova univerzita, 2008, s. 1662-1667 [cit. 8. 11. 2015]. Dostupné z: https://www.law.muni.cz/sborniky/dp08/files/pdf/sprava/vacok.pdf

24 Viz i PIPKOVÁ, Hana. Kdo by měl rozhodovat o řádném opravném prostředku v azylovém řízení. Práuni praxe. 2001, č. 7, s. 403-417. 
vyváženy samotným složením rozkladové komise, kde byly povinně zastoupeny i nestátní instituce, v kontextu azylového práva ale nepředstavoval účinný opravný prostředek a pouze oddaloval přístup $\mathrm{k}$ nezávislému přezkumu.

\subsection{Správní soudy jako realizátoři práva na účinný opravný prostř̌edek}

Česká republika tak vzhledem k požadavku účinného opravného prostředku přešla na jednoinstanční správní řízení, od rozkladu upustila a první opravný prostředek nabyl podobu žaloby ve správním soudnictví. ${ }^{25}$ Rozhodnutí Ministerstva vnitra tak byla přímo podrobena kontrole ze strany moci soudní. ${ }^{26}$ Dominujícím byla snaha vyhovět jednomu ze základních požadavků azylového řízení, a to požadavku nezávislosti rozhodování, jeho nestrannosti a rychlosti. ${ }^{27}$

Současná podoba soudního přezkumu rozhodnutí ve věcech mezinárodní ochrany vyplývající především ze snahy řešit vysoký nápad ve věcech mezinárodní ochrany u krajských soudů by nicméně neměla být vnímána jako zapouzdřený stav. V souvislosti s uplynutím transpoziční lhůty procedurální směrnice, absencí odpovídající právní úpravy, příslušné legislativní změny ${ }^{28} \mathrm{v}$ České republice a kroků ze strany Ministerstva spravedlnosti se objevily komentáře představitelů justice týkající se problematických aspektů soudního řízení v azylových věcech. Zachování stávajícího stavu při změně požadavků na rozsah soudního přezkumu a související změny dokazování v soudním řízení mohou vést $\mathrm{k}$ výrazným průtahům ř́zení a $\mathrm{k}$ hromadění žalob v azylových věcech ${ }^{29}$, nebot' soudy nejsou na obdobný přezkum personálně, ani materiálně vybaveny, přičemž v prrípadě dalšího navyšování žádostí může situace vyústit v zásadnější problémy. To oživuje diskuse o jiných koncepčních řešeních, jelikož s ohledem na změny týkající se rozsahu soudního přezkumu je zřejmé, že přezkum v azylových věcech se musí odklonit od kasačního principu, na kterém je správní soudnictví budováno nyní.

Kromě řešení spočívajících v personálním a materiálním posílení soudů, je cestou obnovení diskusí na téma specializovaného soudu, případně nezávislého specializovaného tribunálu, tedy jistého kvazisoudního tělesa, materiálně vykonávajícího kontrolní funkci

25 Viz novelizace provedená zákonem č. 217/2002 Sb.

26 Dle \31 zákona č. 150/2002 Sb., soudní rád správní, o žalobách rozhoduje specializovaný samosoudce.

27 Viz bod 18 preambule procedurální směrnice.

28 Novela zákona o azylu č. 314/2015 Sb., účinná od 18. 12. 2015, nepřinesla ve vztahu k rozsahu soudního přezkumu žádnou změnu; důvodová zpráva k navrhované novele v podstatě konstatovala soulad stávající úpravy s požadavky plynoucími z procedurální směrnice.

29 Viz kup̌r. vyjádření Josefa Baxy in MALECKÝ, Robert. Pelikánův úřad zaspal. Česku hrozí, že se na jeho území budou hromadit žadatelé o azyl. In: Hlídací pes [online]. Pub. 3. července 2015 [cit. 8. 11. 2015]. Dostupné z: http://hlidacipes.org/ pelikanuv-urad-zaspal-cesku-hrozi-ze-se-na-jeho-uzemi-budou-hromadit-zadatele-o-azyl/ 
soudư ${ }^{30}$. Mezi nesporné výhody těchto modelů lze řadit především specializovanost osob, které se na řízení podílejí, u tribunálu včetně možné přítomnosti odborníků „neprávníkư “ a kompetence k udělení mezinárodní ochrany. ${ }^{31}$ Právě otázka odbornosti a personálního obsazení tělesa se jeví být klíčovou, přičemž možnost flexibilnějšího jmenování členů tribunálu, respektive možnost participace „nesoudcư“, může být jednou ze zásadních výhod kvazisoudního tělesa. Je si nicméně potřeba uvědomit, že Českou republiku ke změně nenutí její mezinárodní závazky (včetně těch vyplývajících z členství k Evropské unii), a konečné řešení bude závislé především na politické vůli. Zatímco případné vytvoření „specializovaného soudu“ prostrednictvím úpravy prríslušnosti koncentrující azylové věci na jeden soud, který by byl náležitě personálně, odbornostně i materiálně posílen, je realizovatelné na legislativní úrovni, přijetí koncepce tribunálů by vyžadovalo rozsáhlé systémové změny, a to včetně těch ústavních. ${ }^{32}$ Přestože možnost zavedení nezávislých tribunálů by umožňovala reagovat na specifika přezkumu ve věcech mezinárodní ochrany, otevírá také řadu problémů spojených s faktickými garancemi nezávislosti, statusem rozhodujících osob apod. Navzdory těmto skutečnostem však lze říct, že koncepce rozsahu přezkumu azylových žádostí plynoucí z procedurální směrnice dostává diskusi o specializaci přezkumu, at’ už formou specializovaného soudu, či specializovaného kvazisoudního tělesa, na novou úroveň. Inspiraci a zdroje pro př́padnou analýzu lze přitom najít hned v několika státech napříč Evropskou unií, protože modely specializovaných soudů zvolila kupřr. Francie a Švédsko a specializované tribunály pak fungují v Belgii, v Irsku, na Maltě, Kypru, v Polsku a ve Spojeném království. ${ }^{33}$

Skutečností zůstává, že diskuse týkající se problémů spojených s realizací článku 46 procedurální směrnice měla být vedena dlouho před uplynutím transpoziční lhůty. V současné době totiž soudy stojí před nelehkým úkolem dostát požadavkům plynoucím z nové koncepce soudního přezkumu bez ohledu na personální a materiální vybavenost.

30 Podrobně k problematice tribunálů viz KRYSKA, David. Idea nezávislých správních tribunálů a její možné uplatnění v cizineckém a azylovém právu se zaměřením na českou a polskou právní úpravu. In: JÍLEK, Dalibor a Pavel POŘÍZEK (eds.). Návratová smèrnice: vyhošténí, zajištèni a soudni prezkeum. Sborník z védeckého semináre uskutečnèného dne 20. řjna 2011 v Kancelári veréjnébo ochránce práv - „Náuratová" smèrnice (2008/115/ES): rok první [online]. Brno: Kancelář veřejného ochránce práv, 2012, s. $273-315$ [cit. 8. 11. 2015]. Dostupné z: http://www.ochrance.cz/fileadmin/user_upload/Publikace/Navratova_ smernice_2011.pdf

31 Viz VĚTROVSKÝ, Jaroslav. Výhody a nevýhody přezkumu rozhodnutí ve věcech azylu soudy v rámci správního soudnictví. In: JÍLEK, Dalibor a Renata KLEČKOVÁ. Společný evropský azylový systém: procedurálni smèrnice. Brno: Doplněk, 2006, s. 100.

32 Na obtížnost proveditelnosti zavedení tribunálů poukazuje i Jakub Camrda, viz CAMRDA, Jakub. Podceňované právo azylu. Jiné právo [online]. 2011 [cit. 8. 11. 2015]. Dostupné z: http://jinepravo.blogspot. cz/2011/02/podcenovane-pravo-azylu.html

33 EVROPSKÁ KOMISE. Zpráva Komise Evropskému parlamentu a Radě o uplatňováni smèrnice 2005/85/ES ze dne 1. prosince 2005 o minimálnich normách pro ř́zeni v členských státech pro priznáváni a odnimáni postavení uprchlika. $\operatorname{KOM}(2010) 465$ [online]. Pub. 8. 9.2011 [cit. 8. 11. 2015]. Dostupné z: http://ec.europa.eu/ transparency/regdoc/rep/1/2010/CS/1-2010-465-CS-F1-1.Pdf 


\subsection{Hledání řešení v zákoně o pobytu cizinců}

Jiné řešení, než svěření rozhodování o opravném prostředku přímo soudům, bylo přijato ve věcech cizineckého práva. ${ }^{34} \mathrm{~V}$ této oblasti byla zvolena koncepce zrrízení zvláštního kolegiálního orgánu ${ }^{35}$ jako organizační součásti Ministerstva vnitra, a to Komise pro rozhodování ve věcech pobytu cizinců. I když je Komise zrrízena v rámci ministerstva, členové komise jsou ve svém rozhodování na ministerstvu nezávislißí ${ }^{36}$ jmenuje a odvolává je nicméně ministr. Odbornost rozhodování ze strany Komise podtrhuje jeden z požadavků na její složení, kdy členem komise může být ustanoven pouze ten, kdo má vysokoškolské vzdělání právnického směru získané řádným ukončením studia v magisterském studijním programu. Organizačně-technické zázemí ale poskytuje ministerstvo, což odráží i možnost, aby se na jednotlivých úkonech v rámci řízení podíleli také nečlenové komise, tedy úřední osoby zaměstnané na ministerstvu. Z řešení je čitelné využití ustanovení o komisích rozkladových, přičemž krokem vpřed jsou garance nezávislosti, přestože řešení zůstalo na půl cestě ke skutečně nezávislému orgánu. ${ }^{37}$

Uplatnění obdobného řešení se může na první pohled jevit jako inspirující i pro oblast mezinárodní ochrany. Jako takové by zachovalo princip filtrace rozhodnutí ministerstva, která vykazují vady, vi̊či správnímu soudnictví a umožnilo reagovat na specifika přezkumu v azylových věcech. Jednoznačné pozitivum lze spatřovat v možné participaci nevládního sektoru na rozhodovací činnosti coby členů komisí v kombinaci s požadavkem na odbornost rozhodování daného podmínkou dosažení určitého vzdělání. Faktem však zůstává, že za situace, kdy Komise nenaplňuje atributy nezávislého tribunálu ${ }^{38}$, je nutné rozhodnutí dále podrobit soudnímu přezkumu. To by se samozřejmě odrazilo na samotné délce azylového řízení a př́istup k účinnému prostředku nápravy ve smyslu požadavků unijního práva i Úmluvy o ochraně lidských práva a svobod by se tím pro žadatele pouze oddálil. Př́padné přidání „mezistupně“ v podobě přezkumu obdobnou komisí pro azylové věci by proto zcela neodpovídalo cílům plynoucím z procedurální směrnice.

34 Srov. zák. č. 427/2010 Sb.

$35 \mathrm{Na}$ rozhodování kolegiálního orgánu pamatuje i správní řád, a to v \ 134.

36 Srov. \170a odst. 9 zákona č. 326/1999 Sb. o pobytu cizinců, ve znění pozdějších předpisů.

37 LUPAČOVÁ, Hana. Soudní přezkum azylových a cizineckých věcí. In: JÍLEK, Dalibor a Pavel POŘÍZEK (eds.). Návratová smèrnice: vyhoštèni, zajištèni a soudni prezkum. Sborník z védeckého semináre uskutečnèného dne 20. ríjna 2011 v Kancelári verejného ochránce práv- „Návratová“ smèrnice (2008/115/ES): rok pruni [online]. Brno: Kancelář veřejného ochránce práv, 2012 [cit. 8. 11. 2015]. Dostupné z: http://www.ochrance.cz/ fileadmin/user_upload/Publikace/Navratova_smernice_2011.pdf, s. 258-260.

38 Srovnej také KONDELOVÁ, Alžbeta. Specifika právní ochrany proti vybraným rozhodnutím v cizineckém právu. In: HAVLAN, Petr et al. Dny práva 2013 - Days of Law 2013. Právni ochrana proti nepravomocným správnim aktuim (individuálním i smíseným) [online]. Brno: Masarykova univerzita, 2013 [cit. 8. 11. 2015]. Dostupné z: http://www.law.muni.cz/sborniky/dny_prava_2013/04_Pravni_ochrana_proti_nepravomocnym_spravnim_aktum.pdf, s. 146-148. 


\section{Závěry}

Množství azylových žádostí spojených s uprchlickou krizí a změny související s transpozicí procedurální směrnice vedou $\mathrm{k}$ zásadním diskusím ohledně revize azylových systémů např́íc celou Evropou a nevyhýbají se ani České republice, navzdory tomu, že zde se prozatím počet žadatelů o mezinárodní ochranu zásadně nezvyšuje. Zatímco na úrovni Evropské unie se vedou zejména debaty týkající se možné revize společného azylového systému a pracuje se i s možnostmi jednotného zpracování žádostí, včetně zpracování externího, na vnitrostátní úrovni se pozornost upírá zejména k novým požadavkům kladeným na přzezum rozhodnutí o mezinárodní ochraně. Požadavek úplného a ex nunc posouzení skutkové i právní stránky věci totiž vede $\mathrm{k}$ úvahám o možných koncepčních úpravách způsobu přezkumu v azylových věcech, které navíc nezaznívají poprvé. Agenda azylového práva je poměrně specifickou oblastí vyžadující vysokou odbornost, schopnost práce s množstvím zdrojů týkajících se informací o zemi původu, jazykové znalosti apod. a s ohledem na novou koncepci přezkumu specifickou i z hlediska procesního vymezení přezkumu. Je tak otázkou, zda je nadále možné (a vhodné) ponechat azylové věci v kompetenci soudů, bez toho, aby došlo k výrazněǰ̌í specializaci, než je svěření agendy specializovaným samosoudcům. Každé z možných řešení s sebou však nese určitá rizika, proto bez ohledu na to, $\mathrm{k}$ jakému řešení se politická reprezentace přikloní, bude nezbytná pečlivá analýza tak, aby nedošlo $\mathrm{k}$ omezení př́stupu ke skutečně účinnému - tedy jak spravedlivému, tak efektivnímu - prostředku nápravy. 